\title{
IMPLEMENTASI PENGAMALAN NILAI-NILAI PANCASILA MELALUI PEMBELAJARAN KOOPERATIF TIPE JIGSAW DI KELAS 5C SDN CIWANGI
}

\author{
Ahmad Saekhu HM, Yuda Prihatono \\ SDN Ciwangi , Kabupaten Purwakarta
}

\section{Kata Kunci :}

Pembelajaran Kooperatif

Tipe Jigsaw.

\begin{abstract}
The low understanding of $5^{\text {th }}$ grades students on the values of Pancasila is caused by the learning method applied by the teacher. As a result, students who are less focused during learning so that the material delivered cannot be absorbed properlyAlternative learning models in an effort to create a learning process that encourages active students in this study is to apply the Jigsaw cooperative learning model. The purpose of this study were: (1) to determine the learning outcomes on social studies learning the material of Pancasila values before the teacher applied the Jigsaw cooperative learning model, (2) to determine the activities of students in the social studies learning process apply the Jigsaw cooperative learning model, and (3) to find out the learning outcomes on social studies material on Pancasila values after the teacher applies the Jigsaw cooperative learning model.
\end{abstract}

Email penulis:

ahmadsaekhuhm@gmail.com

\begin{abstract}
ABSTRAK
Rendahnya pemahaman materi nilai-nilai Pancasila siswa kelas 5C disebabkan oleh metode pembelajaran yang diterapkan oleh guru. Akibatnya, siswa yang kurang fokus selama mengikuti pembelajaran sehingga materi yang disampaikan tidak dapat diserap dengan baik. Alternatif model pembelajaran dalam upaya untuk menciptakan proses pembelajaran yang mendorong siswa aktif dalam penelitian ini adalah dengan menerapkan model pembelajaran kooperatif tipe Jigsaw. Tujuan penelitian ini adalah: (1) untuk mengetahui hasil belajar siswa pada pembelajaran IPS materi nilai-nilai Pancasila sebelum guru menerapkan model pembelajaran kooperatif tipe Jigsaw, (2) untuk mengetahui aktivitas siswa dalam proses pembelajaran IPS dengan menerapkan model pembelajaran kooperatif tipe Jigsaw, dan (3) untuk mengetahui hasil belajar siswa pada pembelajaran IPS materi nilai-nilai Pancasila setelah guru menerapkan model pembelajaran kooperatif tipe Jigsaw.
\end{abstract}

\section{PENDAHULUAN}

Pembukaan Undang-Undang Dasar Negara Republik Indonesia Tahun 1945 yang antara lain menyebutkan, bahwa salah satu tujuan membentuk pemerintahan negara Indonesia adalah mencerdaskan kehidupan bangsa secara menyeluruh. UUD 1945, pada pasal 28c (hasil amandemen) menyebutkan, bahwa salah satu hak asasi manusia adalah hak mendapatkan pendidikan dan mendapatkan manfaat dari ilmu pengetahuan dan teknologi, seni dan budaya 
demi meningkatkan kualitas hidupnya demi kesejahteraan umat manusia, serta pasal 31 tentang Pendidikan.

Dalam Undang-undang Nomor 20 tahun 2003 tentang Sistem Pendidikan Nasional, khususnya pasal 4 ayat (5) menyebutkan bahwa pendidikan diselenggarakan dengan mengembangkan budaya membaca, menulis, dan berhitung bagi segenap warga masyarakat. Karena pentingnya pendidikan bagi bangsa Indonesia, maka pemerintah berusaha dengan berbagai bentuk pendidikan yang diharapkan akan dapat membangun dan mengembangkan sifat-sifat yang mencerminkan nilai-nilai luhur Pancasila, diantaranya dengan diselenggarakannya pendidikan formal. Pendidikan formal merupakan pendidikan yang telah menjadi program pemerintah yang memiliki tujuan yang hendak dicapai dalam pendidikan nasional adalah sumberdaya manusia yang memiliki kekuatan spiritual keagamaan, pengendalian diri, kepribadian, kecerdasan, akhlak mulia serta keterampilan yang dibutuhkan dirinya, masyarakat dan negara.

Perubahan yang begitu cepat sehingga menyebabkan seluruh tatanan yang ada di dunia ikut berubah, sementara itu tatanan yang baru belum terbentuk. Hal tersebut menyebabkan sendisendi kehidupan yang selama ini diyakini kebenarannya menjadi usang. Nilai-nilai yang menjadi panutan hidup telah kehilangan otoritasnya sehingga manusia menjadi bingung. Kebingungan tersebut menimbulkan berbagai krisis, terutama ketika krisis moneter yang dampaknya terasa sekali di berbagai bidang, yang sekaligus juga berpengaruh di bidang moral, serta sikap perilaku manusia. Maka dari itu, dunia pendidikan dituntut untuk mempersiapkan siswa yang memiliki kompetensi multidimensional sesuai dengan tujuan pendidikan nasional dalam mencapai generasi emas Indonesia.

Untuk merespons kondisi tersebut, perlu upaya untuk mengantisipasinya agar tidak menuju pada keadaan yang lebih memprihatinkan. Salah satu solusi yang dapat dilakukan dalam menjaga nilai-nilai panutan hidup dalam berbangsa dan bernegara secara lebih efektif adalah melalui bidang pendidikan, karena pendidikan merupakan sebuah proses pendewasaan manusia menuju pada perubahan positif mental spiritual yang menjadi tanggung jawab bersama antara keluarga, masyarakat, dan pemerintah.

Tugas seorang guru sebagai pengelola pembelajaran adalah menciptakan kegiatan pembelajaran yang memungkinkan siswa mampu mengikuti kegiatan belajar dengan baik dan dapat mencapai hasil belajar yang optimal. Keberhasilan proses pendidikan dapat ditentukan oleh efektif atau tidaknya metode dan strategi yang cocok dalam pembelajaran.

Proses pembelajaran PPKn yang masih didominasi oleh guru, berlangsung secara kaku, serta kurang mendukung aspek pengetahuan, sikap, dan keterampilan, serta proses komunikasi cenderung masih satu arah, dan metode pembelajaran yang dilakukan berupa ceramah, tanya jawab, dan pemberian tugas klasikal.

Permasalahan yang terjadi ini diduga salah satunya adalah akibat kurang bervariasinya pemilihan model pembelajaran dengan materi pembelajaran yang sesuai oleh guru. Siswa hanya mendapatkan informasi pada apa yang disampaikan guru dan siswa cenderung pasif karena hanya bertindak sebagai pendengar setia dan pemerhati apa yang dijelaskan oleh guru. Hasilnya siswa tidak tahu dan kurang mengerti dengan apa yang disampaikan guru. Memperhatikan hasil belajar siswa kelas 5c SDN Ciwangi pada mata pelajaran Pendidikan Kewarganegaraan khususnya dalam aspek sikap tampaknya belum optimal, banyak faktor 
yang menentukan, salah satunya adalah penulis berkeyakinan penerapan moral dalam mata pelajaran pendidikan kewarganegaraan disinyalir jarang dilaksanakan.

Pentingnya suatu strategi pembelajaran untuk meningkatkan aktivitas siswa dan hasil belajar pada muatan mata pelajaran PPKn, maka diperlukan adanya pembelajaran yang menekankan pada belajar siswa aktif di mana proses pembelajaran terdapat partisipasi aktif dari siswa sehingga dalam proses pembelajaran akan terjadi komunikasi yang aktif multiarah baik guru dengan siswa dan antar siswa itu sendiri. Alternatif model pembelajaran dalam upaya untuk menciptakan proses pembelajaran yang mendorong siswa aktif adalah dengan menerapkan model pembelajaran Kooperatif tipe Jigsaw.

Model pembelajaran Kooperatif tipe Jigsaw merupakan fokus dalam pembelajaran PPKn yang mencakup masalah tertutup dengan solusi tunggal, masalah terbuka dengan solusi tidak tunggal, dan masalah dengan berbagai cara penyelesaian. Untuk meningkatkan kemampuan memecahkan masalah perlu dikembangkan keterampilan memahami masalah, membuat model IPS, menyelesaikan masalah, dan menafsirkan solusinya (BSNP, 2006, hlm. 27).

\section{KAJIAN PUSTAKA}

Pembelajaran kooperatif merupakan kerja kelompok, tetapi tidak semua kerja kelompok merupakan pembelajaran kooperatif. Terdapat lima unsur dasar yang membedakan pembelajaran kooperatif dengan kerja kelompok biasa, yaitu:

1. Saling ketergantungan positif (positive interdependence), adalah persepsi bahwa setiap anggota kelompok memiliki kontribusi sama dan saling ketergantungan satu sama lain secara positif untuk mencapai keberhasilan kelompok.

2. Interaksi bertatap muka (face-to-face interaction). Anggota-anggota kelompok perlu berinteraksi dengan bertatap muka langsung supaya bisa saling membantu, menolong, melakukan diskusi, dan meningkatkan kemampuan satu sama lain untuk mencapai tahap pembelajaran maksimum.

3. Akuntabiliti Individu (indivudual accountability). Setiap anggota kelompok mempunyai tanggung jawab untuk belajar. Pembelajaran kooperatif bukan hanya bertujuan untuk mencapai keberhasilan secara kelompok saja, tetapi juga bertujuan untuk memastikan setiap anggota kelompok memiliki kemampuan. Artinya, setelah kelompok berhasil menyelesaikan tugas, setiap anggota kelompok harus mampu menyelesaikan tugas yang sama secara individu.

4. Keterampilan kooperatif (cooperative skills). Siswa harus belajar tentang keterampilan kooperatif yang diperlukan untuk membentuk kelompok yang produktif. Keterampilan-keterampilan ini dapat mengajarkan siswa untuk dapat melakukan komunikasi dalam kelompok, memperbaiki proses pembuatan keputusan, memberi dan menerima kepercayaan, mengambil dan menerima tanggungjawab, dan menghormati hak orang lain.

5. Pemrosesan kelompok (group processing). Proses penyelesaian masalah yang dihadapi kelompok harus dilakukan secara bersama-sama. Sehingga dapat dilakukan suatu penilaian terhadap kinerja kelompok tersebut, yang mengandung arti bahwa setelah tujuan kelompok tercapai maka dapat dilakukan introspeksi kelompok yang dilakukan oleh masing-masing anggota kelompok itu sendiri.

Dalam pembelajaran kooperatif, siswa dilatih untuk memiliki tanggung jawab terhadap keberhasilan kelompoknya. Setiap siswa di dalam kelompok memiliki tanggung jawab dalam menyelesaikan permasalahan yang dihadapi kelompoknya, sehingga keberhasilan 
kelompok sangat dipengaruhi oleh kemampuan, kontribusi, dan interaksi anggotanya. Hal ini karena setiap anggota kelompok dianggap memiliki kontribusi yang sama.

Carin (dalam Shadiq 2004, hlm.18) mengungkapkan ciri-ciri pembelajaran kooperatif adalah: (1) Setiap anggota memiliki peran; (2) Terjadi hubungan interaksi langsung di antara siswa; dan (3) Setiap anggota kelompok bertanggungjawab atas belajarnya dan teman-teman sekelompok tidak menerima saran dan kritik yang tidak membangun.

Menurut Widyantini (2006, hlm. 10-14) menjelaskan, secara keseluruhan ada sepuluh dasar atau prinsip dari pembelajaran kooperatif yaitu sebagai berikut:

a. Positif interdependence, artinya saling bergantung secara positif dimana setiap siswa pada satu kelompok mengeluarkan pendapat dan mendengarkan pendapat siswa lain;

b. Individual accountability, artinya setiap siswa berpeluang mengemukakan pendapatnya;

c. Equal participation, artinya ada pengumpulan keputusan atu pendapat yang sama dari pendapat tiap siswa dalam satu kelompok;

d. Simultaneous interaction, artinya berinteraksi serentak secara bersamaan untuk menyelesaikan masalah atau menjawa pertanyaan;

e. Para siswa memiliki persepsi bahwa mereka "tenggelam atau berenang bersamasama";

f. Para siswa memiliki tanggung jawab terhadap siswa lain dalam kelompoknya, di samping tanggung jawab terhadap diri sendiri, dalam mempelajari materi yang diajarkan;

g. Para siswa harus berpandangan bahwa mereka semuanya memiliki tujuan yang sama;

h. Para siswa harus membagi tugas dan berbagi tanggung jawab sama besarnya diantara para anggota kelompok;

i. Para siswa berbagi kemampuan sementara mereka memperoleh keterampilan bekerja sama selama belajar;

j. Para siswa diminta memeprtanggungjawabkan secara individual materi yang ditangani dalam kelompok kooperatif.

Pembelajaran kooperatif (cooperative learning) mempunyai tiga tujuan penting (Depdiknas, 2004, hlm, 11), diantaranya:

a. Hasil belajar akademik

Pendekatan kooperatif bertujuan untuk meningkatkan kinerja siswa dalam tugas-tugas akademik.

b. Penerimaan terhadap keragaman

Pendekatan kooperatif bertujuan agar siswa dapat menerima teman-temannnya yang mempunyai berbagai macam pembedaan latar belakang. Perbedaan tersebut antara lain perbedaan suku, agama, kemampuan akademik dan tingkat sosial.

c. Pengembangan keterampilan sosial

Metode kooperatif bertujuan untuk mengembangkan keterampilan sosial siswa. Keterampilan sosial yang dimaksud dalam pembelajaran kooperatif adalah berbagai tugas, aktif bertanya, menghargai pendapat orang lain, menstimulus teman untuk bertanya, mau menjelaskan ide atau pendapat, bekerja dalam kelompok, dan sebagainya.

Model pembelajaran kooperatif tipe Jigsaw ini pertama kali dikembangkan oleh Aronson dkk (dalam Widyantini, 2006, hlm. 5). Model pembelajaran kooperatif tipe Jigsaw, Depdiknas (2004, hlm. 14) dalam pembelajaran siswa bergabung dalam kelompok yang 
terdiri dari 4-6 orang dengan kelompok heterogen dan menggunakan kelompok asal dan ahli, siswa mempelajari materi dalam kelompok ahli kemudian membantu anggota kelompok asal mempelajari materi tersebut, kemudian siswa diberikan tugas. Pendekatan pembelajaran ini, siswa bergabung dalam kelompok kecil, kemudian setiap individu siswa diberikan permasalahan dan setelah memahami permasalahan, mereka bergabung dengan siswa dari kelompok lain yang mendapatkan permasalahan yang sama ke dalam satu kelompok disebut kelompok ahli. Setelah seluruh anggota kelompok ahli memperoleh suatu pemecahan, mereka kembali ke kelompok asal dan selanjutnya bertanggungjawab untuk menyampaikan pemahamannya kepada anggota kelompok asalnya. Pada kegiatan akhir pembelajaran setiap siswa diberikan tes soal keseluruhan materi secara individual.

Pembelajaran kooperatif tipe Jigsaw ini dapat mengembangkan aspek kognitif sekaligus mengembangkan keterampilan sosial dan afektif siswa. Dalam proses pembalajaran dengan menggunakan pendekatan kooperatif tipe Jigsaw, siswa akan mendengarkan satu sama lain dan belajar menghargai orang lain. Siswa mengembangkan rasa saling ketergantungan dan tanggung jawab secara mutual karena setiap siswa memerlukan kontribusinya masingmasing dengan sub unit materi yang dikuasainya.

Ada beberapa variasi dalam jenis Jigsaw ini. Jigsaw Aronson dikenal sebagai Jigsaw I, sedangkan selanjutnya dikembangkan antara lain oleh Slavin (1980, Jigsaw II) dan Kagan, 1985, Jigsaw III. Jigsaw juga menekankan segi kompetisi antar grup. Dengan demikian baik kooperatif maupun persaingan individual tetap muncul. Jigsaw III utamanya digunakan dalam kelas dengan dua bahasa (bilingual classroom).

Di bawah ini merupakan setting penyelenggaran metode pembelajaran kooperatif tipe Jigsaw:

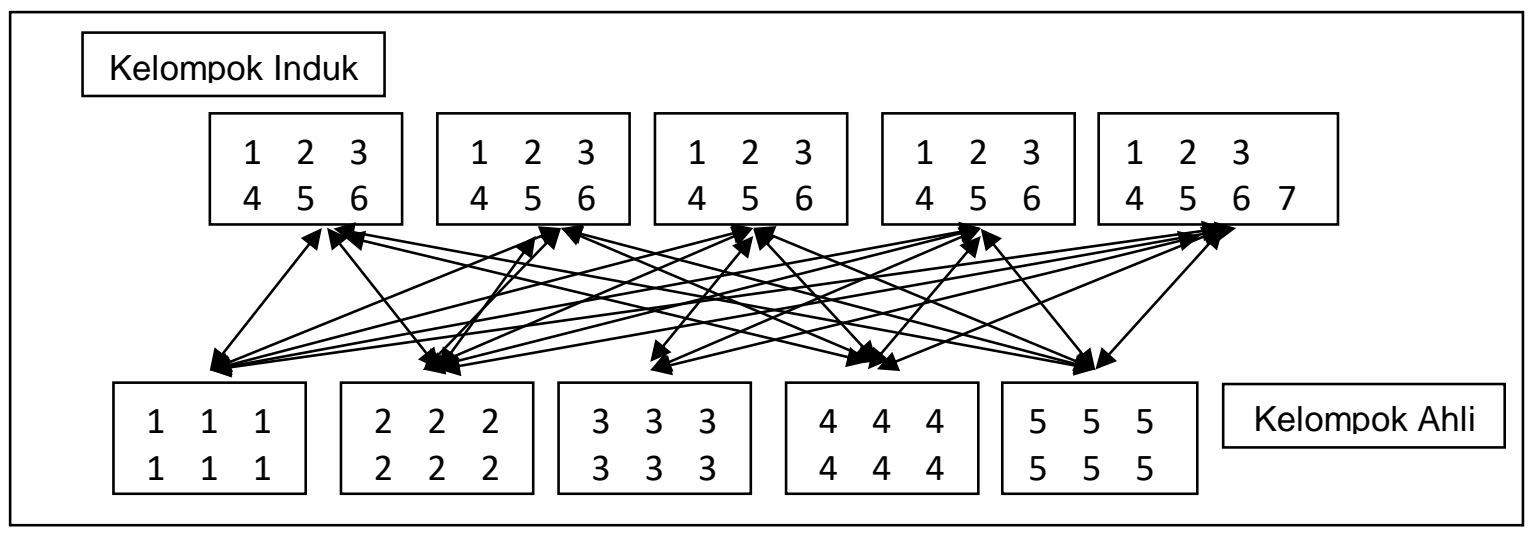

Gambar 2.1 Pemetaan Jigsaw

Manfaat pembelajaran kooperatif menurut Tim (MKPBM, 200, hlm. 219) diantaranya adalah: (1) Mengembangkan dan menggunakan keterampilan berpikir kritis dan kerjasama kelompok; (2) Membangun hubungan antar pribadi yang positif di antara siswa yang berasal dari latar belakang yang berbeda-beda (suku, tingkat sosial ekonomi, kepandaian, dan lainlain); dan (3) Menciptakan hasil kerjasama yang baik.

Pelaksanaan pembelajaran kooperatif supaya berjalan dengan baik, maka upaya yang harus dilakukan guru adalah sebagai berikut: 
1. Senantiasa mempelajari teknik-teknik penerapan model pembelajaran pembelajaran kooperatif di kelas dan menyesuaikan dengan materi yang akan diajarkan.

2. Pembagian jumlah siswa yang merata, dalam artian tiap kelas merupakan kelas heterogen.

3. Diadakan sosialisasi dari pihak terkait tentang teknik pembelajaran pembelajaran kooperatif.

4. Meningkatkan sarana pendukung pembelajaran terutama buku sumber.

5. Mensosialisasikan kepada siswa akan pentingnya sistem teknologi dan informasi yang dapat mendukung proses pembelajaran.

Pelaksanan model pembelajaran kooperatif tipe Jigsaw menurut Shadiq (2004, hlm. 15) langkah-langkah pembelajarannya adalah sebagai berikut:

1. Guru menjelaskan materi yang akan dibahas dan aturan mainnya.

2. Membagi siswa ke dalam kelompok induk, yang terdiri dari 6 kelompok, 4 kelompok beranggota 6 orang dan 1 kelompok beranggotakan 7 orang. Kemudian siswa diberi nomor urut sesuai jumlah anggota, misalnya:

\begin{tabular}{|c|c|c|c|c|}
\hline Induk 1 & Induk 2 & Induk 3 & Induk 4 & Induk 5 \\
\hline $\begin{array}{lll}1 & 2 & 3\end{array}$ & $\begin{array}{lll}1 & 2 & 3\end{array}$ & & $\begin{array}{lll}1 & 2 & 3\end{array}$ & $\begin{array}{lll}1 & 2 & 3\end{array}$ \\
\hline $\begin{array}{lll}4 & 5 & 6\end{array}$ & 456 & 456 & 456 & $\begin{array}{llll}4 & 5 & 6 & 7\end{array}$ \\
\hline
\end{tabular}

3. Siswa yang bernomor urut sama berkelompok membentuk kelompok ahli.

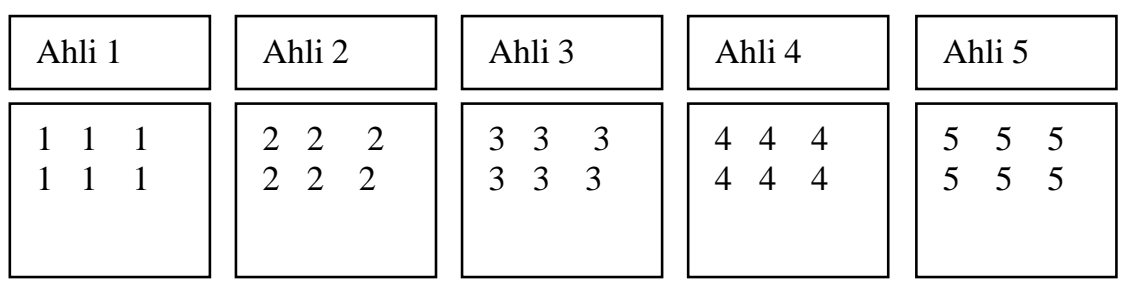

4. Guru membagi kartu pembelajaran pada masing-masing kelompok ahli kartu dapat berupa pertanyan.

5. Kelompok ahli berdiskusi untuk membahas permasalahan yang ada dalam kartu pembelajaran. Setiap anggota memberikan pendapat dan mencatat hasil pembahasan.

6. Masing-masing anggota kelompok ahli kembali ke kelompok induk, kemudian melaporkan hasil diskusi pada rekan dalam kelompoknya.

7. Prestasi kelompok induk. Kelompok lain yang sama kartunya dapat memberikan masukan atau koreksi.

8. Guru memberikan penguatan atau penegasan tentang hasil diskusi.

Evaluasi dapat berupa tanya jawab atau tes lisan, dan pemberian tugas (Uji pemahaman siswa tentang materi yang baru selesai dibahas).

\section{METODE PENELITIAN}

Penelitian ini bersifat melakukan perbaikan pembelajaran. Oleh karena itu, metode yang digunakan adalah metode Penelitian Tindakan Kelas (Action Research Class Room), yakni studi sistematis yang dilakukan dalam upaya memperbaiki praktik-praktik pendidikan dengan melakukan tindakan praktis serta refleksi dari tindakan tersebut (Kasbolah K., 1998/1999, hlm.14).

Secara umum, prosedur penelitian yang digunakan dalam penelitian ini berbentuk siklus. Tiap siklus menghasilkan peningkatan dan perbaikan proses pembelajaran. Metode yang digunakan dalam penelitian ini berbentuk spiral seperti yang dikembangkan oleh Kemmis 
dan Taggart, yaitu 1) tahap perencanaan (planning), 2) tahap pelaksanaan tindakan (acting), 3) tahap observasi (observing), dan 4) tahap refleksi (reflecting).

Penelitian ini dilaksanakan di Sekolah Dasar Negeri Ciwangi Kecamatan Bungursari Kabupaten Purwakarta. Subjek penelitian adalah siswa kelas 5c SDN Ciwangi sebanyak 31 orang, dengan rincian 19 orang laki-laki dan 12 orang perempuan.

\section{PEMBAHASAN}

Guru menjelaskan materi yang akan dibahas dan aturan mainnya. Guru menstimulus ide, gagasan, dan motivasi siswa dengan memberikan narasi tentang contoh perilaku yang sesuai dengan nilai-nilai yang terkandung dalam sila Pancasila, yakni membantu orang yang membutuhkan. Secara interaktif, guru memberikan penjelasan mengenai nilai-nilai yang terkandung dalam sila-sila Pancasila.

Guru membagi siswa satu kelas menjadi 5 (tujuh) kelompok, 4 kelompok terdiri 6 (enam) orang, dan 1 kelompok terdiri 7 (tujuh) orang dengan kemampuan yang berbeda. Kelompok ini disebut kelompok asal (induk).

Maksud dari pembentukan kelompok adalah untuk memudahkan dalam memberikan materi pembelajaran PPKn dengan menerapkan model pembelajaran kooperatif tipe Jigsaw, dan siswa yang sudah paham dengan materi yang sudah di kuasai tidak bosan dengan materi yang diajarkan.

Guru membagikan nomor urut kepada siswa tiap kelompok Siswa yang bernomor urut sama berkelompok membentuk kelompok ahli. Guru membagikan membagikan kartu pembelajaran berupa pertanyaan dan gambar lambang Negara Garuda Pancasila kepada tiaptiap kelompok ahli.

Dalam kelompok ahli, siswa mendiskusikan bagian materi pembelajaran yang sama yaitu sikap-sikap yang sesuai dengan nilai-nilai yang terkandung dalam sila Pancasila, serta menyusun rencana bagaimana menyampaikan kepada temannya jika kembali ke kelompok asal. Setiap anggota kelompok ahli kembali ke kelompok asal memberikan informasi yang telah diperoleh atau dipelajari dalam kelompok ahli.

Setiap anggota kelompok ahli kembali ke kelompok asal (induk) dan memberikan informasi yang telah diperoleh atau dipelajari dalam kelompok ahli. Setiap kelompok induk diminta menganalisis sikap-sikap yang sesuai dengan sila-sila Pancasila, menuliskan sikap-sikap dalam kehidupan sehari-hari yang sesuai dengan nilai-nilai yang terkandung dalam sila-sila Pancasila, bisa memperhatikan perilaku orang-orang di sekitarnya, baik di sekolah, rumah, maupun masyarakat

Guru memfasilitasi diskusi kelompok baik yang ada pada kelompok ahli maupun kelompok asal. Selanjutnya dilakukan presentasi masing-masing kelompok atau dilakukan pengundian salah satu kelompok untuk menyajikan hasil diskusi kelompok yang telah dilakukan agar guru dapat menyamakan persepsi pada materi pembelajaran yang telah didiskusikan.

Selanjutnya dilakukan presentasi masing-masing kelompok atau dilakukan pengundian salah satu kelompok untuk menyajikan hasil diskusi kelompok yang telah dilakukan agar guru dapat menyamakan persepsi pada materi pembelajaran yang telah didiskusikan. Guru memberikan kuis untuk siswa secara individual. Guru memberikan penghargaan pada 
kelompok melalui skor penghargaan berdasarkan perolehan nilai peningkatan hasil belajar individual dari skor dasar ke skor kuis berikutnya

Guru memberikan kuis untuk siswa secara individual. Guru memberikan penguatan atau penegasan tentang hasil diskusi.

Pada kegiatan penutup, siswa diberikan test evaluasi secara individual kemudian dikumpulkan dan dinilai oleh guru. Hasil dari tes dapat dilihat pada tabel 3.1.

\section{Tabel 3.1}

\section{Nilai Hasil Evaluasi}

\begin{tabular}{|l|l|l|}
\hline No & Siswa & Nilai \\
\hline 1. & S.01 & 80 \\
\hline 2. & S.02 & 80 \\
\hline 3. & S.03 & 90 \\
\hline 4. & S.04 & 70 \\
\hline 5. & S.05 & 70 \\
\hline 6. & S.06 & 70 \\
\hline 7. & S.07 & 80 \\
\hline 8. & S.08 & 70 \\
\hline 9. & S.09 & 80 \\
\hline 10. & S.10 & 90 \\
\hline 11. & S.11 & 100 \\
\hline 12. & S.12 & 70 \\
\hline 13. & S.13 & 90 \\
\hline 14. & S.14 & 80 \\
\hline 15. & S.15 & 70 \\
\hline 16. & S.16 & 90 \\
\hline & & \\
\hline
\end{tabular}

\begin{tabular}{|l|l|l|}
\hline No & Siswa & Nilai \\
\hline 17. & S.17 & 100 \\
\hline 18. & S.18 & 80 \\
\hline 19. & S.19 & 90 \\
\hline 20. & S.20 & 100 \\
\hline 21. & S.21 & 100 \\
\hline 22. & S.22 & 90 \\
\hline 23. & S.23 & 90 \\
\hline 24. & S.24 & 70 \\
\hline 25. & S.25 & 80 \\
\hline 26. & S.26 & 80 \\
\hline 27. & S.27 & 90 \\
\hline 28. & S.28 & 70 \\
\hline 29. & S.29 2.30 & 80 \\
\hline 30 & S.30 & 100 \\
\hline 31. & S.31 & 80 \\
\hline Jumlah & 2.580 \\
\hline Rata-rata & 83,22 \\
\hline
\end{tabular}

Aktivitas siswa selama pembelajaran berlangsung sangat besar. Kerja sama antar anggota dalam kelompok pun terlihat lebih baik. Hal ini disebabkan karena penjelasan materi yang diberikan menggunakan peraga yang dapat dipahami dan peran anggota kelompok ahli setelah kembali ke kelompok induk dapat menjelaskan kepada anggotanya. Siswa pun nampak lebih senang dan asyik mengerjakan tugas yang diberikan. Dari segi materi pelajaran sesuai dengan yang direncanakan pada rencana pembelajaran.

Adapun hasil observasi terhadap aktivitas kelompok dengan penilaian terhadap aspek 1) menjelaskan, 2) kerjasama, dan 3) sikap sosial, diperoleh data sebagai berikut: 
Tabel 3.2

Hasil Observasi Aktivitas Kelompok

\begin{tabular}{|c|l|c|c|c|l|}
\hline \multirow{2}{*}{ No } & \multirow{2}{*}{ Kelompok } & \multicolumn{3}{|c|}{ Aspek pengamatan } & \multirow{2}{*}{$\begin{array}{l}\text { Rata- } \\
\text { Rata }\end{array}$} \\
\cline { 3 - 6 } & & Menjelaskan & Kerjasama & Sikap sosial & 3,67 \\
\hline 1 & MELATI & 4 & 4 & 3 & 3 \\
\hline 2 & MAWAR & 4 & 4 & 3 & 3,67 \\
\hline 3 & HARIMAU & 4 & 4 & 3 & 3,00 \\
\hline 4 & GAJAH & 3 & 2 & 2 & 3,33 \\
\hline 5 & KANCIL & 4 & 4 & 2,80 & 3,53 \\
\hline \multicolumn{2}{|l|}{ Rata-Rata } & 3,80 & 3,80 & & \\
\hline
\end{tabular}

Keterangan:

$4,00-3,01=$ baik sekali

$3,00-2,01=$ baik

$2,00-1,01=$ cukup

$\leq 1 \quad=$ kurang

Dari tabel di atas dapat diketahui bahwa hasil penilaian terhadap menjelaskan kelompok mendapat nilai rata-rata 3,80 (baik sekali), penilaian terhadap kerja sama kelompok memperoleh nilai 3,80 (baik sekali), dan penilaian terhadap sikap sosial kelompok memperoleh nilai 2,80 (baik). Secara keseluruhan penilaian terhadap kelompok memperoleh nilai rata-rata 3,47 (baik sekali).

\section{KESIMPULAN DAN SARAN-SARAN}

Hasil belajar PPKn siswa kelas 5c SDN Ciwangi dengan mengimplementasikan pembelajaran kooperatif tipe Jigsaw menunjukkan hasil yang bagus. Hal tersebut terlihat dari perolehan nilai siswa pada nilai rata-rata tes.

Aktivitas siswa kelas 5c SDN Ciwangi selama proses pembelajaran dengan penerapan model pembelajaran kooperatif tipe Jigsaw sudah sangat baik. Pengamalan nilai-nilai Pancasila dalam pembelajaran sudah nampak, dtunjukkan oleh siswa, mulai dari pendahuluan proses pembelajaran sampai kegiatan penutup proses pembelajaran.

Guru hendaknya lebih terampil lagi dalam memilih pendekatan, model, metode, dan strategi pembelajaran dengan cara memperkaya variasi dalam pembelajaran supaya siswa tidak mengalami kejenuhan. Untuk meningkatkan kemampuan profesional, guru harus aktif dalam kegiatan gugus (KKG) dan pengembangan profesi lainnya. Dalam menerapkan model pembelajaran kooperatif tipe Jigsaw pada pembelajaran PPKn di sekolah dasar, guru hendaknya memperhatikan materi yang akan disampaikan serta sarana dan persiapan guru dalam melaksanakan pembelajaran agar tidak terjadi kesenjangan dalam melaksanakan tugas yang diberikan di dalam kelompok

\section{REFERENSI}

Bahri Djumarah S. (2001). Strategi Belajar Mengajar. Jakarta: Rineka Cipta BSNP, (2006). Standar Kompetensi dan Kompetensi Dasar Mata Pelajaran Matematika. Jakarta: Depdiknas 
Cucu Komara dan Deuis Fitri. (2000). Strategi Belajar Tuntas. Bandung: CV. Media Imtaq. Depdiknas. (2003). Undang-Undang RI Nomor 20 Tahun 2003 Tentang Sistem Pendidikan Nasional. Jakarta: Depdiknas

Depdiknas, (2004). Kurikulum Berbasis Kompetesi, Jakarta: Depdiknas

Dimyati dan Moedjiono. (1989). Strategi Belajar Pembelajaran. Jakarta: Depdikbud.

Fokky, F. dkk. (2018). Spiritualisme Pancasila. Jakarta: Prenadamedia Group

Ischak, dkk., (1998). Pendidikan IPS I. Jakarta: Uneversitas Terbuka

Kasbolah, K. (1998/1999). Penelitian Tindakan Kelas. Jakarta: Depdikbud

Rochiati, W. (2006). Metode Penelitian Tindakan Kelas. Bandung: Remaja Rosdakarya

Sapriya, dkk. (2006). Pembelajaran dan Evaluasi Hasil Belajar IPS. Bandung: UPI PRESS.

Shadiq, Ahmad. (2004). Cooperatif Learning. Jakarta: PT. Rineka Cipta

Sujana, N. dan Rivai, A. (2005). Media Pengajaran. Bandung: Sinar Baru Algensindo.

Sumaatmadja. N, dkk. (2002). Konsep Dasar IPS. Jakarta: Depdikbud

Suparno, P. (2000). Filsafat Konstruktivisme dalam Pendidikan. Jakarta: Kanisius

Trianto. (2007). Model-model Pembelajaran Inovatif Berorientasi Kontruktivistik. Jakarta: Prestasi Pustaka.

Wibawa, B. (2003), Penelitian Tindakan Kelas, Jakarta: Depdiknas, Dirjen Dikdasmen, Direktorat Tenaga Kependidikan.

Widyantini. (2006). Model Pembelajaran Dengan Pendekatan Kooperatif. Yogyakarta: PPG-Depdiknas 